\title{
Differences in Antimicrobial Resistance Phenotypes by the Group of CTX-M Extended-Spectrum $\beta$-Lactamase
}

\author{
Bareum Gwon ${ }^{1,2}$, Eun-Jeong Yoon ${ }^{2}$, Dokyun Kim², Hyukmin Lee ${ }^{2}$, Jong Hee Shin ${ }^{3}$, Jeong Hwan Shin', \\ Kyeong Seob Shin ${ }^{5}$, Young Ah Kim ${ }^{6}$, Young $\mathrm{Uh}^{7}$, Hyun Soo Kim ${ }^{8}$, Young Ree Kim ${ }^{9}$, Seok Hoon Jeong \\ ${ }^{1}$ Department of Clinical Pathology, Sangji University College of Science, Wonju, ${ }^{2}$ Department of Laboratory \\ Medicine and Research Institute of Bacterial Resistance, Yonsei University College of Medicine, Seoul, \\ ${ }^{3}$ Department of Laboratory Medicine, Chonnam National University School of Medicine, Gwangju, ${ }^{4}$ Department \\ of Laboratory Medicine, Inje University Busan Paik Hospital, Busan, ${ }^{5}$ Department of Laboratory Medicine, \\ College of Medicine, Chungbuk National University, Cheongju, ${ }^{6}$ Department of Laboratory Medicine, National \\ Health Insurance Service Ilsan Hospital, Goyang, ${ }^{7}$ Department of Laboratory Medicine, Wonju Severance \\ Christian Hospital, Yonsei University Wonju College of Medicine, Wonju, ${ }^{8}$ Department of Laboratory Medicine, \\ Hallym University College of Medicine, Hwaseong, ${ }^{9}$ Department of Laboratory Medicine, School of Medicine, \\ Jeju National University, Jeju, Korea
}

Background: Escherichia coli and Klebsiella pneumoniae clinical isolates producing CTX-M extendedspectrum $\beta$-lactamases (ESBLs) were assessed for antimicrobial resistance phenotypes varied by group of enzymes.

Methods: A total of 1,338 blood isolates, including 959 E. coli and 379 K. pneumoniae, were studied. All the strains were collected between January and July 2017 from eight general hospitals in South Korea. The species were identified by matrix-assisted laser desorption ionization-time of flight mass spectrometry. Antimicrobial susceptibilities were determined by disk diffusion methods and ESBL phenotypes by double-disk synergy tests using disks containing cefotaxime, ceftazidime, cefepime, aztreonam, and clavulanic acid (CA). The genes for $\beta$-lactamases were identified by PCR and sequencing.

Results: Of total microbes, $31.6 \%$ (303/959) E. coli and $24.0 \%(91 / 379) K$. pneumoniae were resistant to cefotaxime and $28.1 \%(269 / 959)$ E. coli and $20.1 \%$
(76/379) K. pneumoniae were CTX-M-type ESBL producers. Among the detected CTX-M ESBLs, $58.0 \%(156 / 269)$ in $E$. coli and $86.8 \%(66 / 76)$ in $K$. pneumoniae belonged to group 1, 46.8\% (126/269) in $E$. coli and $14.5 \%(11 / 76)$ in $K$. pneumoniae were group 9. Ten $E$. coli and one $K$. pneumoniae isolates co-produced both groups of CTX-M ESBL. The group 1 CTX-M producers had a higher level of resistance to cefotaxime, ceftazidime, cefepime, and aztreonam and exhibited stronger synergistic activities when combined with CA compared to group 9.

Conclusion: ESBL phenotypes differ by CTX-M ESBL group and phenotype testing with drugs including $4^{\text {th }}$ generation cephalosporins and monobactams is critical for screening CTX-M-producers with better sensitivity. (Ann Clin Microbiol 2019;22:1-8)

Key Words: CTX-M, Escherichia coli, Extended-spectrum $\beta$-lactamase, Klebsiella pneumoniae

\section{INTRODUCTION}

Extended-spectrum cephalosporins are one of the preferred choice for empirical therapy for infections by Gram-negative bacteria. However, dissemination of the extended-spectrum $\beta$ lactamases (ESBLs) conferring resistance to wide-range of $\beta$ - lactams including the $3^{\text {rd }}$ and $4^{\text {th }}$ generation cephalosporins and monobactams, complicates antimicrobial therapy in the clinical settings [1].

Among over 10 families of ESBLs documented to date [2], the plasmid-mediated cefotaximase CTX-M is the most rapidly growing family with a significant clinical impact [3]. The

Received 26 July, 2018, Revised 11 September, 2018, Accepted 12 September, 2018

Correspondence: Eun-Jeong Yoon, Department of Laboratory Medicine and Research Institute of Bacterial Resistance, Yonsei University College of Medicine, 211 Eonju-ro, Gangnam-gu, Seoul 06273, Korea. (Tel) 82-2-2019-3783, (Fax) 82-2-2019-3784, (E-mail) ejyoon@yuhs.ac

(c) The Korean Society of Clinical Microbiology.

() This is an Open Access article distributed under the terms of the Creative Commons Attribution Non-Commercial License (http://creativecommons.org/licenses/by-nc/4.0) which permits unrestricted non-commercial use, distribution, and reproduction in any medium, provided the original work is properly cited. 
CTX-M ESBL was first identified in Japan [4] and designated in Germany [5]. The growing family consists with heterogeneous groups of enzymes. The amino acid sequence alignment of CTX-M variants categorized the enzymes into five groups, i.e., 1, 2, 8, 9, and 25, sharing $>94 \%$ amino acid identity within a group and $\leq 90 \%$ amino acid identity between groups [6]. The groups are also differed by the hydrolytic property. The first cefotaximase CTX-M-3, renamed from FEC-1, did not confer resistance to ceftazidime [4] and the following CTX-M variants also confer resistance to cefotaxime. The C7 $\beta$-amino thiazol-oxyimino-amide side chain protected the ceftazidime against majority of the CTX-M ESBLs [7]. However, some CTX-M ESBLs, mostly belonging to the group 1, had broader substrate-spectrum including ceftazidime resulting in varied resistance phenotypes. For instance, the dominant CTX-M ESBL CTX-M-15 a representative group 1 enzyme confers resistance to ceftazidime, while the other dominant CTX-M-14 a representative group 9 CTX-M ESBL does not.

Clavulanic acid (CA) is an effective inhibitor for ESBL including CTX-M, and the combination with amoxicillin and ticarcillin, which are both good substrates for the ESBLs, are used in the clinical settings for the infection treatment [8]. By using this activity, CA is widely used for synergy test to detect ESBL producers in the laboratory [9]. CA induces the AmpC production, which can mask the synergistic effects of cephalosporins with CA by inhibiting ESBLs when a bacterial host carries both an ESBL and an AmpC [10].

The differed activity and spectrum between the groups of CTX-M ESBLs are empirical facts, however the phenotypic differences are indeed controversial. Thereby, this study was designed to evaluate the differences in resistance phenotypes by the group of CTX-M ESBLs.

\section{MATERIALS AND METHODS}

\section{Bacterial strains}

Non-duplicate 1,338 blood isolates including 959 E. coli and 379 K. pneumoniae were collected between January and July 2017 from eight general hospitals participating in Korea GLobal Antimicrobial resistance Surveillance System. The species were identified by matrix assisted laser desorption ionization-time of flight mass spectrometry using MALDI Biotyper ${ }^{\circledR}$ (Bruker Daltonik GmbH, Bremen, Germany) and/or $16 \mathrm{~S}$ rDNA sequencing.

\section{Antimicrobial susceptibility and double-disk synergy testing}

Antimicrobial susceptibilities to cefotaxime, ceftazidime, cefepime, and aztreonam were tested by the disk diffusion method on Mueller-Hinton agar (Difco Laboratories, Detroit, MI, USA), following the Clinical and Laboratory Standards Institute guidelines [11]. Further ESBL-testing was conducted for the isolates non-susceptible to both cefotaxime and/or ceftazidime, following the EUCAST guidelines [12] with slight modification. Both E. coli ATCC 25922 and Pseudomonas aeruginosa ATCC 27853 were used for quality control of each batch of experiment. Double-disk synergy test (DDST) was performed using disks (Oxoid Ltd., Basingstoke, UK) containing cefotaxime (30 $\mu \mathrm{g})$, ceftazidime (30 $\mu \mathrm{g})$, cefepime (30 $\mu \mathrm{g})$, aztreonam $(30 \mu \mathrm{g})$, and CA $(10 \mu \mathrm{g})$. The CA disk was freshly made using $6 \mathrm{~mm}$-sized filter disks (Adventec Toyo Kaisha, Ltd., Tokyo, Japan). The inhibition zone diameters of each drug and enlarged zone of inhibition toward a CA disk were recorded and the synergy by CA (SC) was determined by dividing the enlarged zone diameter toward a CA disk with the original zone diameter.

Table 1. The $3^{\text {rd }}$ and $4^{\text {th }}$ generation cephalosporins and monobactam susceptibilities of Escherichia coli and Klebsiella pneumoniae blood isolates*

\begin{tabular}{|c|c|c|c|c|c|c|c|c|c|c|c|c|}
\hline \multirow{2}{*}{ Isolates } & \multicolumn{3}{|c|}{ Cefotaxime } & \multicolumn{3}{|c|}{ Ceftazidime } & \multicolumn{3}{|c|}{ Cefepime } & \multicolumn{3}{|c|}{ Aztreonam } \\
\hline & $\mathrm{R}$ & I & $\mathrm{S}$ & $\mathrm{R}$ & I & $\mathrm{S}$ & $\mathrm{R}$ & I & $\mathrm{S}$ & $\mathrm{R}$ & I & $\mathrm{S}$ \\
\hline $\begin{array}{l}\text { E. coli } \\
\qquad(\mathrm{n}=959)\end{array}$ & $\begin{array}{c}303 \\
(31.6 \%)\end{array}$ & $\begin{array}{c}14 \\
(1.5 \%)\end{array}$ & $\begin{array}{c}642 \\
(66.9 \%)\end{array}$ & $\begin{array}{c}106 \\
(11.0 \%)\end{array}$ & $\begin{array}{c}70 \\
(7.3 \%)\end{array}$ & $\begin{array}{c}783 \\
(81.6 \%)\end{array}$ & $\begin{array}{c}189 \\
(19.7 \%)\end{array}$ & $\begin{array}{c}92 \\
(9.5 \%)\end{array}$ & $\begin{array}{c}678 \\
(70.7 \%)\end{array}$ & $\begin{array}{c}180 \\
(18.8 \%)\end{array}$ & $\begin{array}{c}38 \\
(4.0 \%)\end{array}$ & $\begin{array}{c}741 \\
(77.3 \%)\end{array}$ \\
\hline $\begin{array}{l}\text { K. pneumoniae } \\
(\mathrm{n}=379)\end{array}$ & $\begin{array}{c}91 \\
(24.0 \%)\end{array}$ & $\begin{array}{c}0 \\
(0 \%)\end{array}$ & $\begin{array}{c}288 \\
(76 \%)\end{array}$ & $\begin{array}{c}76 \\
(20.0 \%)\end{array}$ & $\begin{array}{c}5 \\
(1.3 \%)\end{array}$ & $\begin{array}{c}298 \\
(78.6 \%)\end{array}$ & $\begin{array}{c}74 \\
(19.5 \%)\end{array}$ & $\begin{array}{c}13 \\
(3.4 \%)\end{array}$ & $\begin{array}{c}292 \\
(77 \%)\end{array}$ & $\begin{array}{c}81 \\
(21.4 \%)\end{array}$ & $\begin{array}{c}2 \\
(0.5 \%)\end{array}$ & $\begin{array}{c}296 \\
(78.1 \%)\end{array}$ \\
\hline $\begin{array}{l}\text { Total } \\
\qquad(\mathrm{n}=1,338)\end{array}$ & $\begin{array}{c}394 \\
(29.5 \%)\end{array}$ & $\begin{array}{c}14 \\
(1.0 \%)\end{array}$ & $\begin{array}{c}930 \\
(69.5 \%)\end{array}$ & $\begin{array}{c}182 \\
(13.6 \%)\end{array}$ & $\begin{array}{c}75 \\
(5.6 \%)\end{array}$ & $\begin{array}{c}1,081 \\
(80.8 \%)\end{array}$ & $\begin{array}{c}263 \\
(19.7 \%)\end{array}$ & $\begin{array}{c}105 \\
(7.8 \%)\end{array}$ & $\begin{array}{c}970 \\
(72.5 \%)\end{array}$ & $\begin{array}{c}261 \\
(19.5 \%)\end{array}$ & $\begin{array}{c}40 \\
(3.0 \%)\end{array}$ & $\begin{array}{c}1,037 \\
(77.5 \%)\end{array}$ \\
\hline
\end{tabular}

*The breakpoints were applied according to the Clinical and Laboratory Standards Institute guideline [11].

Abbreviations: R, resistant; I, intermediate; S, susceptible. 


\section{DNA manipulation and PCR}

Total DNA was extracted by using MG Cell genomic DNA extraction kit (MGmed Inc., Seoul, South Korea) and, by using the extracted total DNA, PCR and sequencing were carried out to detect the genes for carbapenemases, i.e., bla $a_{\mathrm{KPC}}, b l a_{\mathrm{NDM}}$, bla $_{\mathrm{IMP}}, b l a_{\mathrm{VIM}}, b l a_{\mathrm{GES}}$, and bla $a_{\mathrm{OXA}-48}$ [13]; ESBLs, i.e. for

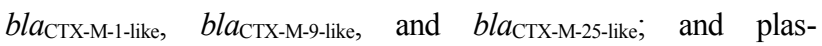
mid-mediated AmpCs, i.e., bla $a_{\mathrm{CMY}}$, bla $a_{\mathrm{DHA}}$, and bla $a_{\mathrm{ACC}}[14,15]$.

\section{Statistical analysis}

Differences existed between groups were calculated by chi-square or $t$-test [16] and the correlation coefficient (r) for simple linear regression was calculated using Pearson's correla- tion [16] by the parametric method, both using SPSS statistics (version 23, IBM Corp., Armonk, NY, USA). All tests were two-tailed, and $P$ value of $<0.05$ was determined to represent statistical significance.

\section{RESULTS}

\section{Resistance to extended-spectrum cephalosporins and aztreo-} nam in $E$. coli and $K$. pneumoniae clinical isoaltes

Of total, 31.6\% (303/959) E. coli and 24.0\% (91/379) $\mathrm{K}$. pneumoniae were resistant to cefotaxime and 19.7\% (n=189) $E$. coli and $19.5 \%(\mathrm{n}=74) \mathrm{K}$. pneumoniae were resistant to cefepime (Table 1). Resistance rates for ceftazidime and aztreonam in E. coli were $11.0 \%(\mathrm{n}=106)$ and $18.8 \%(\mathrm{n}=180)$, respectively, and those in $K$. pneumoniae were $20.0 \%(\mathrm{n}=76)$ and $21.4 \%$
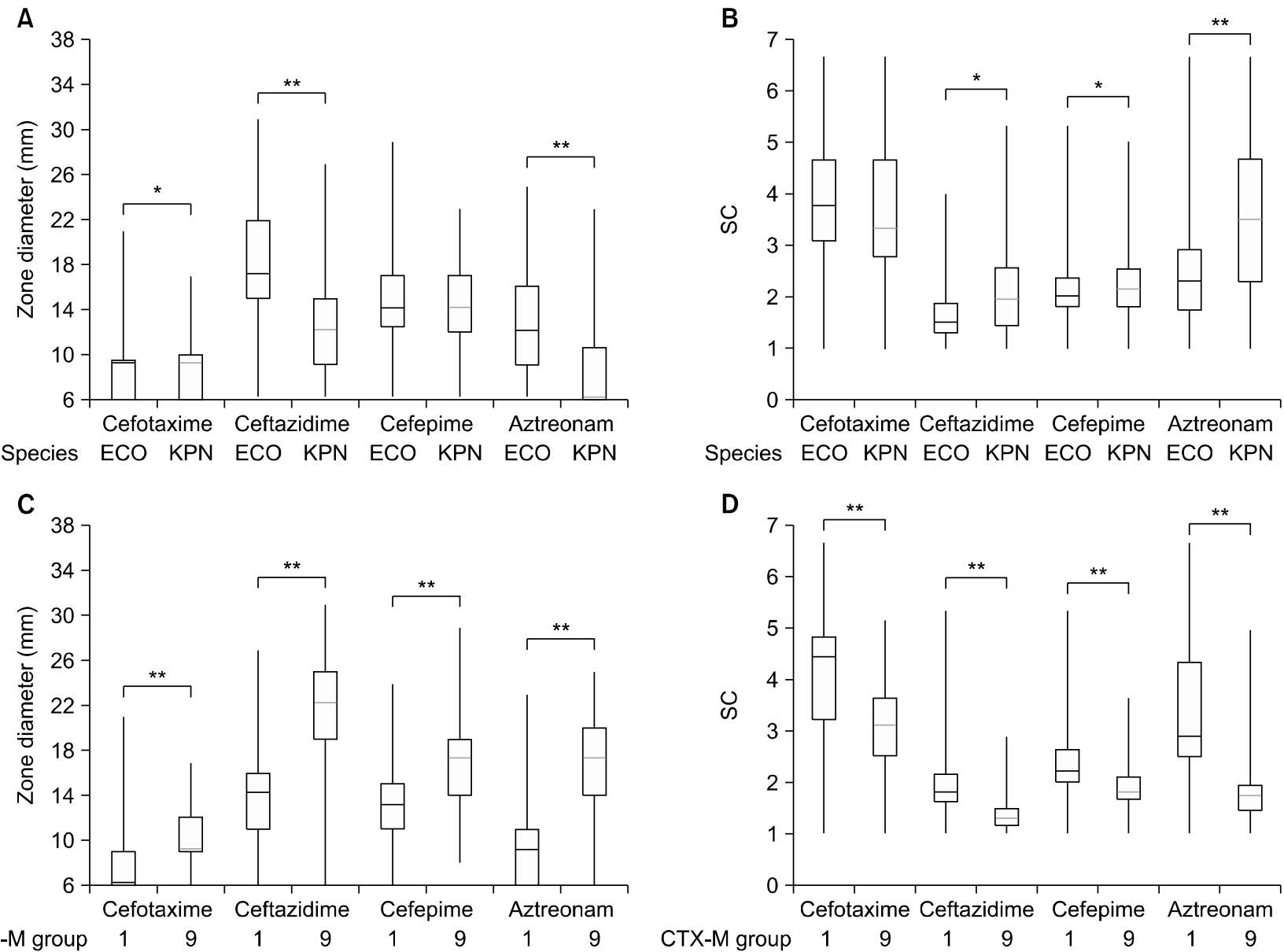

Fig. 1. Zone diameter of the four drugs (A and C) and the synergy with clavulanic acid (SC) (B and D) by bacterial species (A and B) and by groups of CTX-M (C and D). A total of 269 E. coli (ECO) and 76 K. pneumoniae (KPN) CTX-M producers (A and B) including 211 group 1 CTX-M producers and 123 group 9 CTX-M producers (C and D) were plotted. Boxplots present the 1 and 3 quartiles with whiskers showing either the maximum and minimum values. The thick horizontal line indicates median values, black lines for E. coli or group 1 CTX-M and gray lines for $K$. pneumoniae or group 9 CTX-M ESBL producers. The SC value was calculated by dividing the enlarged zone diameter near the CA disk by inhibition zone diameter of each drug. The statistical significance was calculated using Pearson's chi-square test [16] by using SPSS statistics (version 23, IBM Corp., Armonk, NY, USA) and the significance $(P)$ was indicated by using asterisks: $* * P<0.01 ; * P<0.05$. 
$(\mathrm{n}=81)$, respectively. A total of 407 isolates including 315 (32.8\%) E. coli and 92 (24.3\%) K. pneumoniae met criteria for further ESBL-testing [12] and $282 \mathrm{E}$. coli and $88 \mathrm{~K}$. pneumoniae exhibited ESBL phenotypes by DDST.

For the DDST-positive isolates, zone diameters of cefotaxime and cefepime were equivalent by bacterial species, presenting median values of $9 \mathrm{~mm}$ and $14 \mathrm{~mm}$, respectively, while those of ceftazidime $(17 \mathrm{~mm} v s .12 \mathrm{~mm})$ and aztreonam $(12 \mathrm{~mm} v s$. $6 \mathrm{~mm}$ ) were greater in $E$. coli than in K. pneumoniae (Fig. 1A).

\section{CTX-M-type ESBL-producing $E$. coli and $K$. pneumoniae}

Of the DDST-positive isolates, 95.4\% (269/282) E. coli and

Table 2. CTX-M-type ESBL-producing Escherichia coli and Klebsiella pneumoniae

\begin{tabular}{|c|c|c|}
\hline Beta-lactamase & $\begin{array}{l}\text { E. coli } \\
(\mathrm{n}=269)\end{array}$ & $\begin{array}{l}\text { K. pneumoniae } \\
(\mathrm{n}=76)\end{array}$ \\
\hline Group 1 CTX-M producer & $146(54.3 \%)$ & $65(85.5 \%)$ \\
\hline CTX-M-1 & 2 & - \\
\hline CTX-M-3 & 3 & 3 \\
\hline CTX-M-15 & 103 & 43 \\
\hline CTX-M-15, KPC-2 & - & 1 \\
\hline CTX-M-15, CMY-2 & 1 & - \\
\hline CTX-M-15, DHA-1 & - & 11 \\
\hline CTX-M-15, SHV-2, DHA-1 & - & 1 \\
\hline CTX-M-15, SHV-25 & - & 1 \\
\hline CTX-M-15, SHV-28 & - & 1 \\
\hline CTX-M-15, SHV-28, DHA-1 & - & 1 \\
\hline CTX-M-28 & 5 & 1 \\
\hline CTX-M-28, DHA-1 & - & 1 \\
\hline CTX-M-55 & 30 & 1 \\
\hline CTX-M-79 & 1 & - \\
\hline CTX-M-123 & 1 & - \\
\hline Group 9 CTX-M producer & $113(42.0 \%)$ & $10(13.1 \%)$ \\
\hline CTX-M-9 & - & 1 \\
\hline CTX-M-14 & 57 & 4 \\
\hline CTX-M-14, CMY-1 & 1 & - \\
\hline CTX-M-14, DHA-7 & - & 1 \\
\hline CTX-M-14, SHV-27 & - & 1 \\
\hline CTX-M-17 & 18 & 1 \\
\hline CTX-M-24 & 4 & 1 \\
\hline CTX-M-24, DHA-17 & 1 & - \\
\hline CTX-M-27 & 29 & 1 \\
\hline CTX-M-98, DHA-1 & 1 & - \\
\hline CTX-M-113 & 1 & - \\
\hline CTX-M-129 & 1 & - \\
\hline Group 1 and 9 CTX-M co-producer & $10(3.7 \%)$ & $1(1.3 \%)$ \\
\hline CTX-M-15, CTX-M-14 & 3 & - \\
\hline CTX-M-15, CTX-M-17 & 2 & - \\
\hline CTX-M-15, CTX-M-24 & 2 & - \\
\hline CTX-M-15, CTX-M-27 & 2 & 1 \\
\hline CTX-M-15, CTX-M-98 & 1 & - \\
\hline
\end{tabular}

86.4\% (76/88) K. pneumoniae were identified as CTX-M ESBL producers by PCR (Table 2). In both enterobacterial species, the group 1 CTX-M ESBL was more identified than the group 9: 146:113 in E. coli and 65:10 in K. pneumoniae. Ten E. coli and one $K$. pneumoniae co-produced both groups of CTX-M ESBL. Co-carrying $\beta$-lactamase genes were identified in $6.7 \%$ (23/345) CTX-M ESBL producers, including 25.0\% (19/76) $K$. pneumoniae and $1.5 \%(4 / 269)$ E. coli: bla $a_{\mathrm{KPC}-2}$ in one K. pneumoniae, bla $a_{\mathrm{SHV}}$ for ESBL in three K. pneumoniae, both bla $a_{\mathrm{SHV}}$ for ESBL and bla $a_{\mathrm{DHA}}$ in two K. pneumoniae, and bla $a_{\mathrm{DHA}}$ in 13 $K$. pneumoniae, and either of bla $a_{\mathrm{CMY}}$ or bla $a_{\mathrm{DHA}}$ in four E. coli. The CTX-M-negative isolates with ESBL-phenotype included one KPC-2-producing K. pneumoniae and three SHV-12-producing $K$. pneumoniae isolates and the rest 21 isolates were negative for the known ESBLs.

The 222 CTX-M group 1 ESBLs identified were mainly composed with CTX-M-15 (78.4\%, n=174) and CTX-M-55 (14.0\%, $\mathrm{n}=31)$ and CTX-M-28 (3.2\%, n=7), CTX-M-3 (2.7\%, n=6), CTX-M-1 (0.9\%, n=2), CTX-M-79 $(0.5 \%, \mathrm{n}=1)$, and CTX-M$123(0.5 \%, \mathrm{n}=1)$ were followed. The CTX-M group 9 ESBLs mostly comprised CTX-M-14 (50.0\%, 67/134), CTX-M-27 (24. $6 \%, \mathrm{n}=33)$, CTX-M-17 (15.7\%, n=21), and CTX-M-24 (6.0\%, $\mathrm{n}=8)$ and, as minor, CTX-M-98 (1.5\%, n=2), CTX-M-9 (0.7\%, $\mathrm{n}=1)$, CTX-M-113 (0.7\%, n=1), and CTX-M-129 (0.7\%, n=1) were included in the group. Of the 174 CTX-M-15 producers, eleven isolates co-produced group 9 CTX-M ESBLs, such as CTX-M-14 (n=3), CTX-M-27 (n=3), CTX-M-17 (n=2), CTXM-24 (n=2), and CTX-M-98 (n=1).

\section{Resistance phenotypes conferred by CTX-M ESBL}

By the group of CTX-M enzymes, the zone diameters by the disks containing extended-spectrum cephalosporins or monobactams were smaller in group 1 than those in group 9 exhibiting the median values of $6 \mathrm{~mm} v s .9 \mathrm{~mm}$ for cefotaxime, 14 $\mathrm{mm}$ vs. $22 \mathrm{~mm}$ for ceftazidime, $13 \mathrm{~mm}$ vs. $17 \mathrm{~mm}$ for cefepime, and $9 \mathrm{~mm}$ vs. $17 \mathrm{~mm}$ for aztreonam (Fig. 1C). The zone diameters of 11 Enterobacteriaceae producing both group 1 and group 9 CTX-M ESBLs were close to those in group 1 CTX-M ESBL producers rather than those in the group 9 producer: median values at $6 \mathrm{~mm}$ for cefotaxime, $12 \mathrm{~mm}$ for ceftazidime, $11 \mathrm{~mm}$ for cefepime, and $9 \mathrm{~mm}$ for aztreonam. Co-production of either SHV ESBL or AmpC in K. pneumoniae retained the inhibition zone diameters: median values of zone diameter at $9 \mathrm{~mm}$ for cefotaxime, $10 \mathrm{~mm}$ for ceftazidime, $14 \mathrm{~mm}$ for cefepime, and 6 $\mathrm{mm}$ for aztreonam in SHV ESBL co-producers and $9 \mathrm{~mm}$ for 
cefotaxime, $11 \mathrm{~mm}$ for ceftazidime, $14 \mathrm{~mm}$ for cefepime, and $6 \mathrm{~mm}$ for aztreonam in AmpC co-producers. The KPC-2 carbapenemase co-producer exhibited the reduced inhibition zones, 6 $\mathrm{mm}$ for cefotaxime, $9 \mathrm{~mm}$ for ceftazidime, $9 \mathrm{~mm}$ for cefepime, and $6 \mathrm{~mm}$ for aztreonam.

The synergistic effect with CA was evaluated using SC values (Fig. 1B-D). The cefotaxime SC was the greatest (median, 3.66) and followed by those of aztreonam (2.50), cefepime (2.14), and ceftazidime (1.63). The median SC for cefotaxime was greater in $E$. coli than in K. pneumoniae (3.78:3.33), while those of the other three drugs were less in E. coli, 1.56:2.00 for ceftazidime, 2.08:2.19 for cefepime, and 2.36:3.50 for aztreonam. By the group of CTX-M ESBLs, the SCs were always greater in the group $1 \mathrm{CTX}-\mathrm{M}$ ESBL compared to those in the group 9: 4.44:3.11 for cefotaxime, 1.83:1.30 for ceftazidime, 2.23:1.83 for cefepime, and 2.91:1.75 for aztreonam.

The group 9 CTX-M producers displayed stronger linear relationships between cefotaxime SC and either SCs of ceftazidime, cefepime, and aztreonam (Fig. 2) compared to the group 1 CTX-M ESBL producers having correlation coefficients (r): 0.5409:0.4988 for ceftazidime SC, 0.6945:0.4131 for cefepime $\mathrm{SC}$, and 0.7012:0.5753 for aztreonam SC. Slopes were calculated by comparing the SCs for ceftazidime, cefepime, and aztreonam with the cefotaxime SC. The group 1 CTX-M ESBL producers exhibited steeper slopes than the group 9 producers for ceftazidime SC (0.3394:0.1929) and for aztreonam SC (0.6209:0.4989), while no slope difference between the two groups was observed for cefepime SC (0.2783:0.3091).

\section{DISCUSSION}

Continuing increase in CTX-M-type ESBL-producing Enterobacteriaceae, mainly led by the predominant CTX-M-15 of group 1 and CTX-M-14 of group 9 [17], triggers more usage of last options for the treatment resulting in vicious antimicrobial resistance. In South Korea, cefotaxime resistance reached at $38 \%$ for E. coli and at 35\% for K. pneumoniae clinical isolates in 2015 [18] and it was associated with dominance of both CTX-M-15 and -14 since the mid-2010s [19]. The enterobacterial blood isolate collection of seven-month-period in 2017 presented cefotaxime resistance rates at $31.6 \%$ for $E$. coli and at $24.0 \%$ for $K$. pneumoniae, which were less than those in 2015, probably due to the differed specimens and surveillance systems. The dominant type of group 1 was CTX-M-15 (78.4\%) and that of group 9 was CTX-M-14 (50.0\%).

The rate of human carriages of CTX-M producers are increasing [17] and the dissemination is issuing not only among human beings but also for animals [20,21] and environments [22]. The resistance rates for cefotaxime $(5.0 \%)$ and cefepime $(1.4 \%)$ in E. coli from food animals [23] and in Enterobacteriaceae from edible vegetables ( $10.1 \%$ for cefotaxime and $1.1 \%$ for cefepime) [24] were comparably lower than those in clinical isolates. However, the prevalence of CTX-M ESBLs (78.6\% of cefotaxime-resistant E. coli from food animals and $73.7 \%$ of cefotaxime-resistant Enterobacteriaceae from vegetables) and the dominant types of the enzyme (CTX-M-14 and CTX-M-15) corresponded to those of clinical isolates, highlighting the
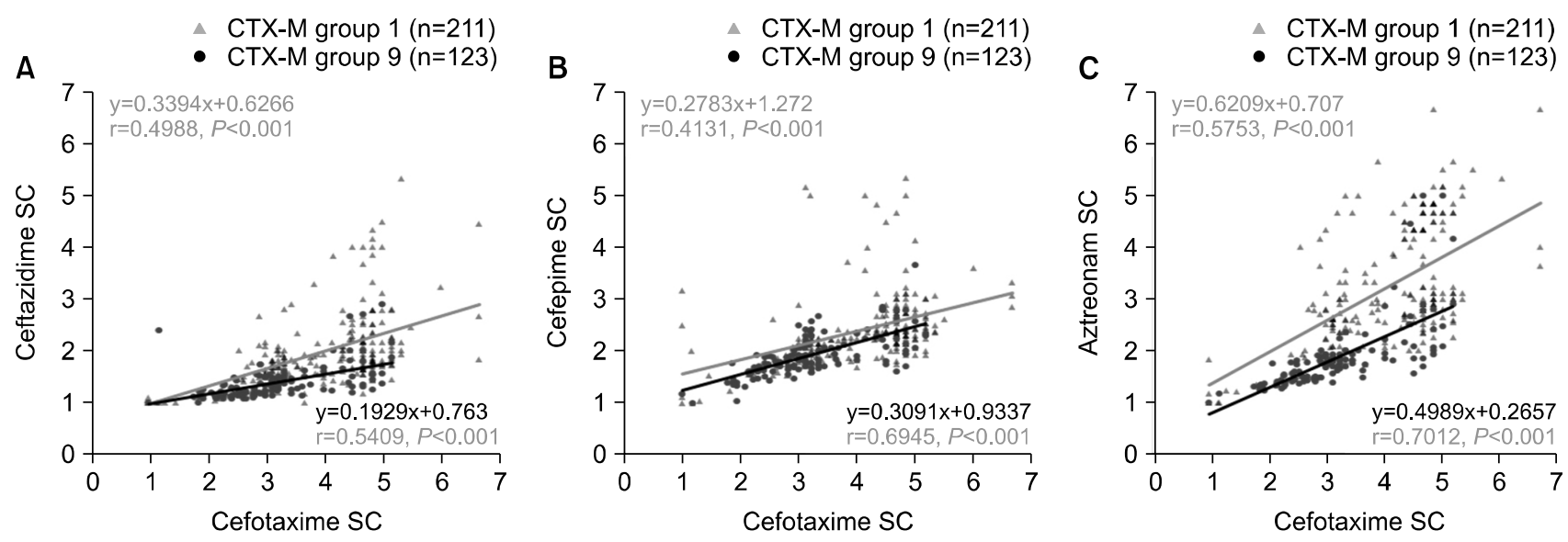

Fig. 2. Correlation between synergy with clavulanic acid (SC) of cefotaxime and ceftazidime SC (A), cefepime SC (B), and aztreonam SC (C). The SC was calculated by dividing the enlarged zone diameter near the clavulanic acid disk by inhibition zone diameter of each drug. The correlation coefficient (r) was calculated using Pearson's correlation [16] by the parametric method using SPSS statistics and the significance $(P)$ was determined by a two-tailed method using the correlation value and the sample size. Each dot indicates one strain, gray triangles and black dots indicate strains producing CTX-M group 1 and group 9, respectively. 
One-Health concepts.

Inhibition zone sizes of the tested drugs were always smaller for the group 1 CTX-M ESBL than those for the group 9 confirming that the group 1 enzyme confers higher level of resistance to the drugs than the group 9 [25]. As well, the SCs, indicating the hydrolytic activity inhibited by $\mathrm{CA}$, were greater for the tested drugs in the group 1 CTX-M ESBL compared to those in the group 9 supporting that the group 1 enzymes hydrolyzed more the drugs than those belonging to the group 9. It is noteworthy that the ceftazidime SC in group 9 CTX-M ESBL is close to 1 , agreeing the point that ceftazidime resistance, which has been used in practice as an indicator of ESBL producers, frequently leads to fail recognizing CTX-M-producers [6]. The higher prevalence of CTX-M ESBLs, which is the case of this study, may elevate the false-negative error rates [26]. Masked synergistic activity with CA by induced AmpC [10] was not observed in this study, doubtlessly because intrinsic AmpC producing enterobacterial species, including Enterobacter spp., Serratia marcescens, and Citrobacter freundii, were not included in the study.

The SCs for ceftazidime and aztreonam compared with that for cefotaxime pronounced well the differed range of substrates by group of CTX-M ESBL. The linear correlation of SCs for ceftazidime and aztreonam with that for cefotaxime in group 1 CTX-M ESBL presented steeper slope than those in group 9 CTX-M ESBL verifying the hydrolytic activity of the group 9 restricted to cefotaxime, while the group 1 has expanded range of the substrate. It correlates well to the biochemical properties demonstrated by kinetic constants [27,28].

Bacterial host itself seemed having little impact on the level of resistance to the tested drugs. CTX-M-producing K. pneumoniae presented higher levels of resistance to ceftazidime and aztreonam compared to E. coli. Since ceftazidime and aztreonam presented greater differences in the group 1 CTX-M compared to cefotaxime and cefepime, it is likely that the higher proportion of group 1 CTX-M in K. pneumoniae than in E. coli led the difference. The SCs differed by the bacterial species were spotted in aztreonam, which is also explained by the predominance of group 1 CTX-M ESBL in $K$. pneumoniae.

Finally, this study confirmed that the phenotype testing with drugs including $4^{\text {th }}$ generation cephalosporins and monobactams is critical for screening the CTX-M-producers with better sensitivity [16]. From $0.9 \%$ to $2.9 \%$ CTX-M ESBL producers had SCs at 1 for at least one drugs, which means no obvious synergistic effect with CA was obtained for cefotaxime $(n=5)$, cefta- zidime $(n=10)$, cefepime $(n=3)$, and aztreonam $(n=5)$. Moreover, four strains $(1.2 \%)$ had both cefotaxime SC and ceftazidime SC at 1 , and the simplified DDST using only the two drugs could have missed the CTX-M ESBL producers. Estimating the group of CTX-M ESBL by DDST was unsound, however evaluating the composition of CTX-M ESBL producer population would be possible somehow by using linear correlation for SCs of cefotaxime SC-ceftazidime SC and cefotaxime SC-aztreonam SC.

This study had aware imperfections: i) the restricted bacterial species, ii) only isolations from blood specimens of patients in one country, and iii) lack of other groups of CTX-M ESBLs, such as the group 2 and the group 25. However, at least, the most clinically relevant panel of ESBL producers in the world, group 1 and 9 CTX-M-producing E. coli and $K$. pneumoniae, were covered and the necessity of complete set of testing drugs for DDST in the medical laboratory was emphasized. The not-yet-determined ESBLs in the strains exhibiting ESBL phenotypes are going to be further studied.

\section{ACKNOWLEDGMENTS}

This research was supported by a fund (2017E4400100\#) from the Research Program of Korea Centers for Disease Control and Prevention.

\section{REFERENCES}

1. Pitout JD and Laupland KB. Extended-spectrum beta-lactamaseproducing Enterobacteriaceae: an emerging public-health concern. Lancet Infect Dis 2008;8:159-66.

2. Paterson DL and Bonomo RA. Extended-spectrum beta-lactamases: a clinical update. Clin Microbiol Rev 2005;18:657-86.

3. D'Andrea MM, Arena F, Pallecchi L, Rossolini GM. CTX-M-type $\beta$-lactamases: a successful story of antibiotic resistance. Int $\mathbf{J}$ Med Microbiol 2013;303:305-17.

4. Matsumoto Y, Ikeda F, Kamimura T, Yokota Y, Mine Y. Novel plasmid-mediated beta-lactamase from Escherichia coli that inactivates oxyimino-cephalosporins. Antimicrob Agents Chemother 1988;32:1243-6.

5. Bauernfeind A, Grimm H, Schweighart S. A new plasmidic cefotaximase in a clinical isolate of Escherichia coli. Infection 1990;18:294-8.

6. Bonnet R. Growing group of extended-spectrum beta-lactamases: the CTX-M enzymes. Antimicrob Agents Chemother 2004;48: 1-14.

7. Delmas J, Leyssene D, Dubois D, Birck C, Vazeille E, Robin F, et al. Structural insights into substrate recognition and product expulsion in CTX-M enzymes. J Mol Biol 2010;400:108-20.

8. Livermore DM. Determinants of the activity of beta-lactamase inhibitor combinations. J Antimicrob Chemother 1993;31 Suppl A:9-21. 
9. Livermore DM, Hope R, Mushtaq S, Warner M. Orthodox and unorthodox clavulanate combinations against extended-spectrum beta-lactamase producers. Clin Microbiol Infect 2008;14 Suppl 1:189-93.

10. Livermore DM, Akova M, Wu PJ, Yang YJ. Clavulanate and beta-lactamase induction. J Antimicrob Chemother 1989;24 Suppl B:23-33.

11. CLSI. Performance standards for antimicrobial susceptibility testing: twenty-fifth informational supplement. CLSI document M100-S25. Wayne, PA: Clinical and Laboratory Standards Institute; 2015.

12. European Committee on Antimicrobial Susceptibility Testing. EUCAST Guideline for the Detection of Resistance Mechanisms and Specific Resistances of Clinical and/or Epidemiological Importance. Version 2.0. Vasel: EUCAST; 2017.

13. Poirel L, Walsh TR, Cuvillier V, Nordmann P. Multiplex PCR for detection of acquired carbapenemase genes. Diagn Microbiol Infect Dis 2011;70:119-23.

14. Ryoo NH, Kim EC, Hong SG, Park YJ, Lee K, Bae IK, et al. Dissemination of SHV-12 and CTX-M-type extended-spectrum beta-lactamases among clinical isolates of Escherichia coli and Klebsiella pneumoniae and emergence of GES-3 in Korea. J Antimicrob Chemother 2005;56:698-702.

15. Pérez-Pérez FJ and Hanson ND. Detection of plasmid-mediated AmpC beta-lactamase genes in clinical isolates by using multiplex PCR. J Clin Microbiol 2002;40:2153-62.

16. Campbell MJ. Statistics at Square Two. London: BMJ Books; 2006.

17. Bevan ER, Jones AM, Hawkey PM. Global epidemiology of CTX-M $\beta$-lactamases: temporal and geographical shifts in genotype. J Antimicrob Chemother 2017;72:2145-55.

18. Kim D, Ahn JY, Lee CH, Jang SJ, Lee H, Yong D, et al. Increasing resistance to extended-spectrum cephalosporins, fluoroquinolone, and carbapenem in Gram-negative bacilli and the emergence of carbapenem non-susceptibility in Klebsiella pneumoniae: analysis of Korean Antimicrobial Resistance Monitoring System (KARMS) data from 2013 to 2015. Ann Lab Med 2017; 37:231-9.

19. Park SH, Byun JH, Choi SM, Lee DG, Kim SH, Kwon JC, et al.
Molecular epidemiology of extended-spectrum $\beta$-lactamaseproducing Escherichia coli in the community and hospital in Korea: emergence of ST131 producing CTX-M-15. BMC Infect Dis 2012;12:149.

20. Stedt J, Bonnedahl J, Hernandez J, Waldenström J, McMahon BJ, Tolf $\mathrm{C}$, et al. Carriage of CTX-M type extended spectrum $\beta$ lactamases (ESBLs) in gulls across Europe. Acta Vet Scand 2015;57:74.

21. Timofte D, Maciuca IE, Williams NJ, Wattret A, Schmidt V. Veterinary hospital dissemination of CTX-M-15 extended-spectrum beta-lactamase-producing Escherichia coli ST410 in the United Kingdom. Microb Drug Resist 2016;22:609-15.

22. Ojer-Usoz E, González D, Vitas AI. Clonal diversity of ESBL-producing Escherichia coli isolated from environmental, human and food samples. Int $\mathrm{J}$ Environ Res Public Health 2017;14:E676.

23. Shin SW, Jung M, Won HG, Belaynehe KM, Yoon IJ, Yoo HS. Characteristics of transmissible CTX-M- and CMY-Type $\beta$ lactamase-producing Escherichia coli isolates collected from pig and chicken farms in South Korea. J Microbiol Biotechnol 2017;27:1716-23.

24. Kim HS, Chon JW, Kim YJ, Kim DH, Kim MS, Seo KH. Prevalence and characterization of extended-spectrum- $\beta$-lactamaseproducing Escherichia coli and Klebsiella pneumoniae in readyto-eat vegetables. Int J Food Microbiol 2015;207:83-6.

25. Bauer AW, Kirby WM, Sherris JC, Turck M. Antibiotic susceptibility testing by a standardized single disk method. Am J Clin Pathol 1966;45:493-6.

26. Maurer FP, Courvalin P, Böttger EC, Hombach M. Integrating forecast probabilities in antibiograms: a way to guide antimicrobial prescriptions more reliably? J Clin Microbiol 2014;52:3674-84.

27. Bonnet R, Recule C, Baraduc R, Chanal C, Sirot D, De Champs C, et al. Effect of D240G substitution in a novel ESBL CTX-M-27. J Antimicrob Chemother 2003;52:29-35.

28. Poirel L, Gniadkowski M, Nordmann P. Biochemical analysis of the ceftazidime-hydrolysing extended-spectrum beta-lactamase CTX-M-15 and of its structurally related beta-lactamase CTX-M-3. J Antimicrob Chemother 2002;50:1031-4. 
$=$ 국문초록=

\section{CTX-M 광범위 베타락탐 분해효소의 그룹별 내성표현형 차이}

${ }^{1}$ 상지대학교 임상병리학과, ${ }^{2}$ 연세대학교 의과대학 진단검사의학교실 및 세균내성연구소,

${ }^{3}$ 전남대학교 의과대학 진단검사의학교실, ${ }^{4}$ 인제대학교 부산백병원 진단검사의학과, ${ }^{5}$ 충북대학교 의과대학 진단검사의학교실, ${ }^{6}$ 국민건강보험 일산병원 진단검사의학과, ${ }^{7}$ 연세대학교 원주의과대학 원주세브란스기독병원 진단검사의학교실,

${ }^{8}$ 한림대학교 의과대학 진단검사의학교실, ${ }^{9}$ 제주대학교 의학전문대학원 진단검사의학교실

권바름 $^{1,2}$, 윤은정 ${ }^{2}$, 김도균 ${ }^{2}$, 이혁민 ${ }^{2}$, 신종희 $^{3}$, 신정환 $^{4}$, 신경섭 $^{5}$, 김영아 $^{6}$, 어 $^{\text {영 }}{ }^{7}$, 김현수 $^{8}$, 김영리 $^{9}$, 정석훈 $^{2}$

배경: CTX-M 광범위 베타락탐 분해효소(CTX-M-type extended-spectrum $\beta$-lactamase, ESBL)를 생성하는 임상검체 분리 장세균을 대상으로 CTX-M 효소의 그룹별 내성표현형의 차이를 비교하였다.

방법: 2017년 1월부터 7월에 국내 8개 종합병원 환자의 혈액에서 분리된 총 1,338주의 장세균(Escherichia coli 959 주 및 Klebsiella pneumoniae 379주)을 대상으로 하였다. 디스크 확산법으로 항균제 감수성을 시험하였고, 3 세대 세팔로스포린 계 세포탁심 및 세프타지딤, 4 세대 세팔로스포린계 세페핌 및 모노박탐계 아즈트레오남과 클라불란산 간의 항균력 상승 작용을 이중 디스크 확산법으로 확인하고, 확장된 억제대의 크기를 측정하였다. 내성유전형은 PCR 및 염기서열분석으 로 확인하였다.

결과: E. coli의 31.6\% (303/959)와 K. pneumoniae의 24.0\% (91/379)가 세포탁심에 내성이었고, E. coli $28.1 \%$ (269/959)와 K. pneumoniae $20.1 \%$ (76/379)에서 CTX-M ESBL 유전자가 검출되었다. E. coli와 K. pneumoniae에서 검출된 CTX-M 유전 자의 $58.0 \%$ (156/269)와 86.8\% (66/76)가 그룹 1 효소였고, $46.8 \%$ (126/269)와 $14.5 \%$ (11/76)는 그룹 9 효소였다. E. coli 10 주와 K. pneumonia 1 주는 CTX-M 그룹 1 과 9 유전자를 모두 지니고 있었다. CTX-M 그룹 1 효소를 생성하는 균주는 그룹 9 효소를 생성하는 균주보다 세포탁심, 세프타지딤, 세페핌 및 아즈트레오남 디스크에 의한 억제대가 작았으며, 클라불란산과의 상승작용에 의해 억제대가 더 크게 확장되는 양상을 보였다.

결론: CTX-M 그룹 1과 그룹 9 효소를 생성하는 균주는 차별되는 내성표현형을 보였다. 이중 디스크 확산법에 의한 CTX-M 효소 생성 균주의 검출 민감도를 높이기 위해서는 3세대 세팔로스포린계 세포탁심과 세프타지딤 디스크뿐 아니 라 4세대 세팔로스포린계 및 모노박탐계 항균제 디스크도 함께 사용하는 것이 요구된다. [Ann Clin Microbiol 2019; 22:1-8]

교신저자 : 윤은정, 06273, 서울시 강남구 언주로 211 연세대학교 의과대학 진단검사의학교실 및 세균내성연구소

Tel: 02-2019-3783, Fax: 02-2019-3784

E-mail: ejyoon@yuhs.ac 